\title{
A Rare Case in Trauma: Hidden Double Danger Lumbar Fracture and Aortic Dissection
}

\author{
Cilem Caltılı*, Burak Demirci and Abuzer Coskun* \\ SBU Bağcılar Training and Research Hospital Emergency Medicine Clinic, Turkey
}

*Corresponding author: Cilem Caltılı, SBU Bağcllar Training and Research Hospital Emergency Medicine Clinic, Central Neighborhood, Dr. Sadık Ahmet Street, Istanbul, Turkey

Abuzer Coskun, SBU Istanbul Bağcılar Training and Research Hospital, Emergency Medicine Clinic, Central Neighborhood, Dr. Sadık Ahmet Street, Istanbul, Turkey

\section{ARTICLE INFO}

Received: 幽 November 11, 2020

Published: 慧 December 09, 2020

Citation: Cilem Caltıl, Burak Demirci, Abuzer Coskun. A Rare Case in Trauma: Hidden Double Danger Lumbar Fracture and Aortic Dissection. Biomed J Sci \& Tech Res 32(3)-2020. BJSTR. MS.ID.005251.

\begin{abstract}
Most of the admissions to hospital emergency services are traumas. Approach to multiple traumas is an important element in emergency services. It is necessary to pay attention to rare but important causes of mortality after high-energy trauma. Traumatic aortic rupture may occur as a result of fractures due to trauma at the spine level. This condition has a high mortality for aortic dissections. We aimed to discuss a 52-year-old male patient who had a compression fracture of lumbar 4 and 5 as a result of a traffic accident and a rare traumatic abdominal aorta rupture.
\end{abstract}

\section{Introduction}

Evaluation of patients with multiple trauma in the emergency department may be prolonged according to the severity of the injury and the accompanying diseases of the patient [1]. While these patients feel pain at a high rate due to the severity of the injury pain, the pain associated with an invisible internal organ or vascular injuries is hidden. Bleeding caused by these hidden injuries can cause blood loss and accordingly hemorrhagic shock. Traumatic hemorrhagic shock is extremely rare even in the largest trauma centers, and it constitutes only $1-2 \%$ of admissions due to trauma [2]. Aortic injuries can rarely be seen in high kinetic energy traumas such as falls from heights, traffic accidents, plane, and railway accidents [3]. Aortic dissection is the separation of the tunica media of the aorta and the filling of blood into the aortic wall as a result of a tear in the aortic intima by various mechanisms [4]. In traumatic aortic rupture, intima, and media lasers are present, but the second lumen does not form in the media [5]. Within the dissected aorta, separate lumens, true and false lumens are formed. They are separated from each other by an intimal membrane called a flap. According to the time-based classification by De Bakey et al., He defines acute dissection in the first 14 days, subacute aortic dissection in the period between 14 days and 2 months, and chronic aortic dissection as dissections that have existed for more than two months [6-8].

The most common classification is that of De Bakey et al., accordingly, dissections starting from the proximal aorta and involving the whole aorta are classified as Type I, while those involving only the ascending aorta are Type II, and those involving only the descending aorta they are called Type III aortic dissections [9]. Another common classification is the Stanford classification. According to this classification, regardless of the distal extension, dissections involving the ascending and aortic aorta are called Type A, and those involving the descending aorta are called Type B [10]. Aortic dissections that occur after acute trauma have high mortality. The mortality rate of Stanford type B aortic dissections involving the descending aorta is quite high, at 50-60\% [11]. Traumatic aortic rupture (AR) is usually fatal (up to $85 \%$ pre-hospital mortality) and is most common in the thoracic descending aorta [12-14]. Traumatic rupture of the aorta may occur as a result of fractures due to traumas at vertebral levels [15-16].In this case report, we aimed to draw attention to traumatic aortic dissection, which is very rare in the literature and can be overlooked in the intensity of emergency department admissions. 


\section{Case Presentation}

A fifty-two-year-old healthy male who had an in-vehicle traffic accident was referred to our emergency department with an ambulance. When the patient's complaints were questioned, he mentioned low back pain and abdominal pain. On admission, Glasgow Coma Score: 15 , cooperative and oriented and his vital signs were normal (blood pressure130/80 $\mathrm{mmHg}$, heart rate $84 /$ minute, respiratory rate $14 /$ minute, Oxygen saturation $\left(\mathrm{SpO}_{2}\right)$ : $94 \%$. Their respiratory and cardiovascular system in physical examination his examination was normal. Sensitivity was detected on palpation over the lumbar (L) vertebra 4-5. Nothing abnormal was detected on palpation of the abdomen. Bilateral 3/5 power loss was present in both lower extremities. Sensory examination was normal. Other physical examination for trauma did not reveal any features. In complete blood count and biochemistry tests, white blood cell counts $12500 / \mathrm{mm}^{3}$, hemoglobin $11,1 \mathrm{~g} / \mathrm{dL}$ hematocrit $33 \%$ were detected. Other laboratory tests were normal. Compression fracture of the L4-5 vertebra was detected in the spinal vertebra computed tomography (Figure 1). In contrast-enhanced thorax and abdominal computed tomography, an appearance compatible with $4 \mathrm{~cm}$ aortic dissection including the aortic arch and the junction of the descending aorta was observed (Type-3 Aortic Dissection) (Figure 2).
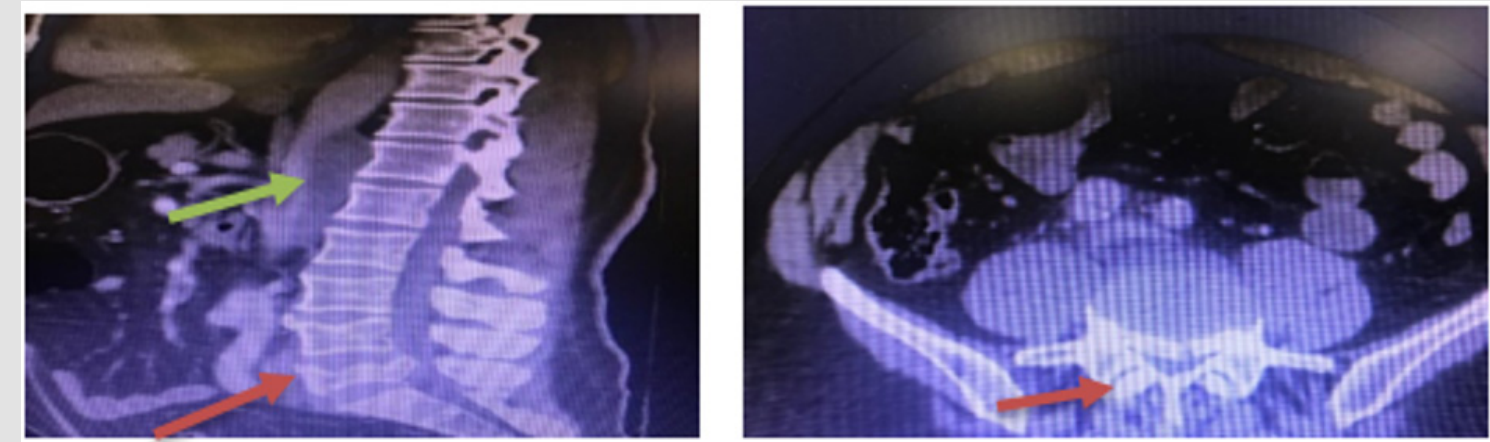

Figure 1: Spinal vertebra computed tomography; Compression fracture of the L4-5 vertebra and canal compression due to the fracture (red arrow). $4 \mathrm{~cm}$ aortic dissection in the abdominal aorta (green arrow).
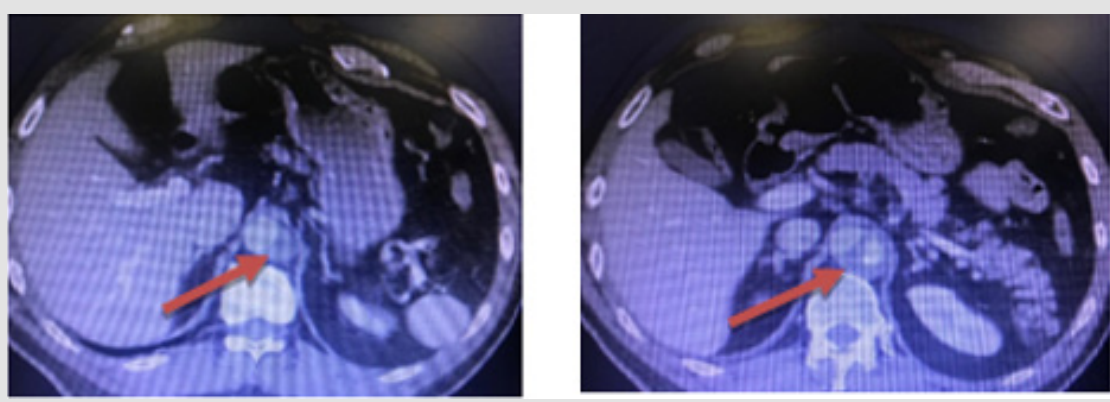

Figure 2: Spinal vertebra computed tomography; Compression fracture of the L4-5 vertebra and canal compression due to the fracture (red arrow). $4 \mathrm{~cm}$ aortic dissection in the abdominal aorta (green arrow).

Due to a lumbar fracture, the patient was consulted with Neurosurgery. He was consulted with cardiovascular surgery due to aortic dissection. The patient was operated by both clinics together. 'Endovascular Aortic Stent Graft' Applied by cardiovascular surgery team. Surgical repair was performed by a neurosurgeon. In the postoperative follow-up, the patient's current loss of strength improved with a slight slump. In the control examination of the patient one month later, it was found that there was an almost complete improvement.

\section{Discussion}

Trauma is one of the leading causes of death between the ages of 1-44 [17]. The most important point in trauma management is the multidisciplinary approach. Another important point is that these patients are managed correctly within the intensity of emergency services, diagnosed, and their follow-up and treatment are arranged with the relevant departments $[1,18]$. Our case was managed together with the neurosurgery and cardiovascular surgery clinic. In patients with multi-trauma, intra abdominal and intra-thorax injuries can be overlooked due to incisions and fractures [2]. Hemorrhagic shock secondary to these injuries is frequently observed in these patients [19]. Aortic dissections after acute trauma have the ratio. In traumatic AR, the rupture of the aortic Wall includes all its multiples. Some aortic injuries do not involve the adventitia and create a false aneurysm and tear within 24 hours in the hypertensive patient, some traumatic false 
aneurysms can remain intact for many years without tearing. The single most important factor in the diagnosis of traumatic AR is to suspect that it may be behind the accompanying injuries [20,21]. In our case, dissection was detected in the contrast-enhanced thoraco abdominal tomography taken upon suspicion after the L4-5 fracture in computed tomography.

The most important and most common complaint in traumatic aortic dissection is retrosternal or interscapular pain. In physical examination, most of the patients do not show any findings related to traumatic $A R$ at the first evaluation [20,22]. In aortic dissection, more strokes are seen in proximal aortic lesions, while paraplegia may occur with the involvement of spinal arteries in distal lesions [23]. In our patient, there was $3 / 5$ weakness in both lower extremities related to dissection. The definitive diagnosis is made by angiography [20-22,24]. Acute proximal dissection has a high mortality rate in all studies. Emergency surgery indications of cases with distal dissection are controversial [25]. Complicated cases and hypertension, organ perfusion disorder, and cases with an increase in aortic diameter benefit from emergency surgery. Studies have shown that emergency surgery, medical treatment, and observation do not affect mortality and morbidity in patients with uncomplicated distal dissection [26]. In our case, surgery was performed due to paraplegia and L4-5 fracture, and postoperative loss of strength improved with mild sequelae. Traumatic AR due to acute trauma is rarely seen in the literature, but its mortality rate is quite high [3]. The mortality rate in Stanford type B aortic dissections is between 50-60\% [27]. With early diagnosis and treatment, death after AR and secondary hemorrhagic shock can be prevented [28]. This rare diagnosis was diagnosed early in our patient and was taken into operation and was discharged with almost complete recovery.

\section{Conclusion}

We wanted to draw attention to the fact that life-threatening injuries hidden behind the visible injuries in trauma patients should not be overlooked in the intensity of emergency services.

\section{Author Contributions}

Conception/Design of study - C.C, B.D; Data acquisition A.C.; Data analysis/Interpretation - B.D.; Drafting manuscript - C.C; Critical revision of manuscript - A.C.; Final approval and accountability - B.D.; Technical or material support - C.C., B.D., Supervision - C.C., D.B., A.C.

\section{Informed Consent}

Written informed consent was obtained from the patient. Ethics Committee Approval: Ethics committee approval was not required for the case report.

\section{Conflict of Interest}

Authors declared no conflict of interest.

\section{Financial Disclosure}

Authors declared no financial support.

\section{Authorship}

The conception and design of the work; the acquisition, analysis, and interpretation of data for the work; drafting the work and revising it critically for important intellectual content; and final approval of the manuscript was done by Abuzer Coşkun, Assoc. Prof., Burak Demirci, MD, and Çilem Çaltılı, MD.

Funding: None declared.

Availability of Data and Materials: All data is available on request without restriction.

Conflict of Interest: None declared.

Informed Consent: Written informed consent was not necessary because the study was performed retrospectively by screening patient files.

Ethical Approval: Written with permission from the patient and local hospital administration.

Human Rights: The study was made in following the Declaration of Helsinki for Human Research.

\section{References}

1. Clkrıklar HI, Yürümez Y, Yücel M, Aslan NA, Engindeniz Z, et al. (2016) Management of Difficult Patients in Emergency the Department. Sakarya Medical Journal 6 (1): 20-26.

2. Holcomb JB, Jenkins D, Rhee P, Jay Johannigman, Peter Mahoney, et al. (2007) Damage control resuscitation: Directly addressing the early coagulopathy of trauma. J Trauma 62(2): 307-310.

3. Özkan S, Koyuncu M, İpekci A, Avşaroğulları L, Dönmez H, et al. (2011) Traumatic aortic dissection: A case report. AKATOS 2(1): 40-43.

4. Robbins RC, McManus RP, Mitchell RS, Latter DR, Moon MR, et al. (1993) Management of patients with intramural hematoma of the thoracic aorta. Circulation 88: 1-10.

5. Klima T, Spjut HJ, Coelho A, Gray AG, Wukasch DC, et al. (1983) The morphology of ascending aortic aneurysms. Hum Pathol 14: 810-817.

6. DeBakey ME, Beall AC, Cooley DA, Crawford ES, Morris GC, et al. (1966) Dissecting aneurysm of the aorta. Surg Clin North Am 46: 1045.

7. Hirst AE, Johns VJ, Kime SW (1958) Dissecting aneurysm of the aorta: A review of 505 cases. Medicine 37(3): 217-219.

8. Levinson DC, Edmeades DT, Griffth GC (1950) Dissecting aneurysm of the aorta: Its clinical, electrocardiographic, and laboratory features. A report of fifty-eight autopsied cases. Circulation 1: 360-387.

9. DeBakey ME, McCollum CH, Crawford ES, Morris GC, Howell J, et al. (1982) Dissecting aneurysm of the aorta: A twenty-year follow-up of five hundred twenty-seven patients treated surgically. Surgery 92: 1118.

10. Nakashima Y, Kurzumi T, Sueshşi K, Tanaka K (1990) Dissecting aneurysm: A clinic pathologic and histopathologic study of 111 autopsied cases. Hum Pathol 21(3): 291-296.

11. Özsöyler İ, Yafla H, Lafçı B, Yılık L, Gürbüz A (2007) Endovascular Treatment in Traumatic Acute Thoracic Aortic Dissection: A Case Report. Turkish J Thorac Cardiovasc Surg 15: 158-161.

12. Leong Tan GW, Pek CH, Wong D, Punamiya S, Ming Terk Chiu, et al. (2011) Management of blunt traumatic thoracic aorta injuries with 
endovascular stent-grafts in a tertiary hospital in an Asian city. Ann Vasc Surg 25: 605-611.

13. Riesenman PJ, Farber MA, Rich PB, Sheridan BC, Robert R Mendes, et al. (2007) Outcomes of surgical and endovascular treatment of acute traumatic thoracic aortic injury. J Vasc Surg 46(5): 934-940.

14. Chock MM, Aho J, Naik N, Clarke M, Stephanie Heller, et al. (2015) Endovascular treatment of distal thoracic aortic transection associated with a severe thoracolumbar spine fracture. Vascular 23: 550-552.

15. Kopp R, Beisse R, Weidenhagen R, Plitz S, Stefan Hauck, et al. (2007) Strategies for prevention and operative treatment of aortic lesions related to spinal interventions. Spine 32: 753-760.

16. Yoshioka Y, Morimoto Y, Sugimoto T, Hiroki Arase, Kota Araki, et al (2016) Blunt abdominal aortic injury associated with L2 vertebral fracture. Ann Vasc Surg 34: 273-276.

17. Brunett PH, Cameron PA (2011) Trauma. In: Tintinalli JE, Stapczynsk JS, Ma OJ, Cline DM, Cydulka RK, et al. (Eds.,). Tintinalli's Emergency Medicine A comprehensive study guide ( $7^{\text {th }}$ Edn.). New York: Mc Graw Hill. pp.1671-1676.

18. Akoğlu H, Denizbașı A, Ünlüer E, Güneysel Ö, Onur O (2005) Demographic Characteristics of Trauma Patients Admitted to Marmara University Hospital Emergency Service. Marmara Medical Journal 18 (3): 113-122.

19. Herkas D (2011) Traumatic hemorrhagic shock: Advances in fluid management. Emerg Med Pract 13 (11): 1-19.

\section{ISSN: 2574-1241}

DOI: 10.26717/BJSTR.2020.32.005251

Cilem Caltılı, Abuzer Coskun. Biomed J Sci \& Tech Res

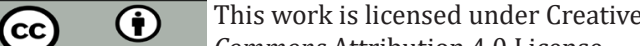

Submission Link: https://biomedres.us/submit-manuscript.php
20. Brown J, Grover FL (1997) Trauma to the Heart. Chest Surg Clin Am 7: 325-341.

21. Akköse Ș, Bulut M, Armağan E, Ateș M (2004) Traumatic Aortic Rupture: A Case Report. National Journal of Trauma 10(1): 57-59.

22. Bowling WM, Wilson RF, Bucham TG (2000) Thoracic Trauma. In: Tintinalli JE, Kelen GD, Stapczynski JS (Eds.,). Emergency Medicine: A Comprehensive Study Guide ( $5^{\text {th }}$ Edn.). New York: Mc Graw Hill. pp. 1675-1699.

23. Demir CF, Artaş H (2007) Spontaneous aortic dissection presenting with recurrent monoplegia in the left arm: A case report. EAJM 39: 151-153.

24. Dahnert WF (1996) Radiology Review Manual ( ${ }^{\text {rd }}$ Edn.). Baltimore: Williams \& Wilkins.

25. Glower DD, Fann JI, Speier RH, Morrison L, White WD, et al. (1990) Comparison of medical and surgical therapy for uncomplicated descending aortic dissection. Circulation 82: 39-46.

26. Görür DA (2006) Type I Aortic Dissection and Angiotensin Preconverting Converting Enzyme (ACE) Gene Polymorphism. Thesis. Istanbul.

27. Özsöyler I, Yafla H, Lafçı B, Yilik L, Gürbüz A (2007) Traumatic Acute Thoracic Aorta Endovascular Treatment in Dissection: A Case Report. Turkish J Thorac Cardiovasc Surg 15: 158-161.

28. Cherkas D (2011) Traumatic hemorrhagic shock: Advances in fluid management. Emerg Med Pract 13 (11): 1-19.

$\begin{array}{ll}\text { BIOMEDICAL } & \text { Assets of Publishing with us } \\ \text { RESEARCHES } & \text { - Global archiving of articles } \\ \text { - Immediate, unrestricted online access } & \text { - Rigorous Peer Review Process } \\ & \text { - Authors Retain Copyrights } \\ & \end{array}$

